NBER WORKING PAPER SERIES

COMPARING PRICE AND NON-PRICE APPROACHES TO URBAN WATER CONSERVATION

\author{
Sheila M. Olmstead \\ Robert N. Stavins \\ Working Paper 14147 \\ http://www.nber.org/papers/w14147 \\ NATIONAL BUREAU OF ECONOMIC RESEARCH \\ 1050 Massachusetts Avenue \\ Cambridge, MA 02138 \\ June 2008
}

The authors are grateful for financial support from the Pioneer Institute for Public Policy Research. The views expressed herein are those of the author(s) and do not necessarily reflect the views of the National Bureau of Economic Research.

NBER working papers are circulated for discussion and comment purposes. They have not been peerreviewed or been subject to the review by the NBER Board of Directors that accompanies official NBER publications.

(C) 2008 by Sheila M. Olmstead and Robert N. Stavins. All rights reserved. Short sections of text, not to exceed two paragraphs, may be quoted without explicit permission provided that full credit, including (C) notice, is given to the source. 
Comparing Price and Non-Price Approaches to Urban Water Conservation

Sheila M. Olmstead and Robert N. Stavins

NBER Working Paper No. 14147

June 2008

JEL No. L95,Q25,Q28

\begin{abstract}
$\underline{\text { ABSTRACT }}$
Urban water conservation is typically achieved through prescriptive regulations, including the rationing of water for particular uses and requirements for the installation of particular technologies. A significant shift has occurred in pollution control regulations toward market-based policies in recent decades. We offer an analysis of the relative merits of market-based and prescriptive approaches to water conservation, where prices have rarely been used to allocate scarce supplies. The analysis emphasizes the emerging theoretical and empirical evidence that using prices to manage water demand is more cost-effective than implementing non-price conservation programs, similar to results for pollution control in earlier decades. Price-based approaches also have advantages in terms of monitoring and enforcement. In terms of predictability and equity, neither policy instrument has an inherent advantage over the other. As in any policy context, political considerations are important.
\end{abstract}

\author{
Sheila M. Olmstead \\ Yale School of Forestry \& Environmental Studies \\ Sage Hall, 205 Prospect Street \\ New Haven, CT 06511 \\ sheila.olmstead@yale.edu \\ Robert N. Stavins \\ JFK School of Government \\ Harvard University \\ 79 JFK Street \\ Cambridge, MA 02138 \\ and NBER \\ robert_stavins@harvard.edu
}


24 consumption during acute shortages due to drought, or in the long run due to constraints on their

\section{Comparing Price and Non-price Approaches to Urban Water Conservation}

\author{
Sheila M. Olmstead and Robert N. Stavins
}

\section{Introduction}

Cities, towns, and villages around the world struggle to manage water resources in the face of population increases, consumer demand for water-intensive services, and increasing costs (including environmental costs) of developing new supplies. In this paper, we provide an economic perspective on reducing urban water demand through pricing and non-price conservation policies. We compare price and non-price approaches to water conservation along five dimensions: the ability of policies to achieve water conservation goals, cost-effectiveness, distributional equity, monitoring and enforcement, and political feasibility.

The worst drought on record continues to unfold in the American southeast, affecting major cities such as Atlanta, Georgia, and Raleigh, North Carolina. In the arid Western U.S., the Colorado River system faces the worst drought on record, lasting (thus far) from 1999 to 2008 and leaving Lake Mead (the source of more than $90 \%$ of Las Vegas's water) about half empty.

Municipal water consumption comprises only about $12 \%$ of total freshwater withdrawals in the United States; and agricultural irrigation, the single largest water use, comprises just over one-third of all withdrawals (Hutson et al. 2004). While analysis suggests that re-allocating water from agriculture to cities would be efficient in many regions, in the current legal and political setting, large-scale transfers of water rights from agriculture to cities are relatively uncommon (Brewer et al. 2007, Brown 2006, Howe 1997). Thus, cities often must reduce water ability to increase supply. 
The efficient water price is the long-run marginal cost (LRMC) of its supply. LRMC

27 reflects the full economic cost of water supply - the cost of transmission, treatment and

28 distribution; some portion of the capital cost of reservoirs and treatment systems, both those in

29 existence and those future facilities necessitated by current patterns of use; and the opportunity

30 cost in both use and non-use value of water for other potential purposes. Many analysts have

31 noted that water prices, for many urban as well as agricultural uses, lie well below LRMC (Sibly

32 2006, Timmins 2003, Hanemann 1997), with significant welfare consequences (Renzetti 1992,

33 Russell and Shin 1996). In the short run, without price increases acting as a signal, water

34 consumption proceeds during periods of scarcity at a faster-than efficient pace. Water

35 conservation takes place only under "moral suasion or direct regulation" (Howe 1997). In

36 contrast, if water prices rose as reservoir levels fell during periods of limited rainfall, consumers

37 would respond by using less water, reducing or eliminating uses according to households'

38 particular preferences. In the long run, inefficient prices alter land-use patterns, industrial

39 location decisions, and other important factors. The sum of all these individual decisions affects

40 the sustainability of local and regional water resources.

41 Implementation of efficient water prices would be challenging, to say the least. Some of

42 the opportunity costs of urban water supply are exceedingly difficult to quantify. What is the

43 value of a gallon of water left instream to support endangered species habitat, for example?

44 While economists have developed a variety of useful methods for estimating such values, the

45 expectation that every water supplier will develop full individual measures of the LRMC of

46 water supply is unrealistic. If LRMC represents an ultimate water pricing goal, there are smaller,

47 less ambitious steps toward efficiency that can be accomplished more readily. 
Even with inefficient prices, injecting better price signals into the processes of water use

49 and allocation can result in important improvements. For example, given a particular public

50 goal, such as the conservation of a particular quantity of water or percentage of current

51 consumption, various policies can be employed, some more costly than others. Choosing the

52 least costly method of achieving some water-provision goal is characterized in economic terms

53 as cost-effective water management. Even if the water conservation goal is, itself, inefficient,

54 society can benefit from the minimization of costs to achieve it.

55 We focus on this issue of policy instrument choice for water conservation, summarizing

56 research from the economics literature, including both our own work on this issue and that of

57 other economists. Given the strong theoretical cost advantages of market-based approaches to

58 water conservation over conventional alternatives, and the emerging empirical evidence for the

59 potential cost savings from moving to market-based approaches to conservation, the time is ripe

60 for a discussion of the relative strengths and weaknesses of these policy instruments.

61

\section{2. Cost-effectiveness of water conservation policies}

63 Decades of theoretical and empirical economic analysis suggest that market-based

64 environmental policies are more cost-effective than conventional policies, often characterized as

65 command-and-control (CAC) or prescriptive approaches. Market-based regulations encourage

66 behavior through market signals rather than through explicit directives regarding conservation

67 levels or methods. These policy instruments, if well-designed and implemented, encourage firms

68 and households to undertake conservation efforts that are in their own interests and collectively

69 meet policy goals. CAC approaches, in contrast, allow little flexibility in the means of achieving 
70 goals and often require households and/or firms to undertake similar shares of a conservation 71 burden regardless of cost.

72 In the area of pollution control, the cost-effectiveness advantage of market-based 73 approaches over CAC policies has been demonstrated theoretically (Pigou 1920, Crocker 1966, 74 Dales 1968, Montgomery 1972, Baumol and Oates 1988) and empirically (Keohane 2007, 75 Teitenberg 2006). Perhaps the best-known application of these principles to environmental 76 regulation is the U.S. $\mathrm{SO}_{2}$ trading program, established under Title IV of the Clean Air Act 77 Amendments of 1990 , which has produced cost savings on the order of $\$ 1$ billion annually 78 (Stavins 2003). Dozens of other market-based policies have been applied to air and water 79 pollution control, fisheries management, and other environmental problems in industrialized and 80 developing countries (Kolstad and Freeman 2007, Stavins 2003, Sterner 2003, Panayotou 1998).

81 Economists' attention has only recently turned to examining the potential economic gains

82 from adopting market-based approaches to water conservation, rather than CAC approaches.

83 Whereas the gains from market-based approaches to pollution control depend critically on

84 heterogeneity in marginal abatement costs across firms (Newell and Stavins 2003), the cost 85 savings from market-based approaches to water conservation derive largely from heterogeneity 86 in households' marginal benefits from water consumption (Mansur and Olmstead 2007). This is 87 because current CAC approaches to water conservation are essentially rationing policies. This 88 makes the application similar to other cases in which rationing has been replaced with price89 based allocation, such as traffic congestion on roadways (Parry and Bento 2002) and at airports 90 (Pels and Verhof 2004). Recent studies demonstrate how raising prices, rather than 91 implementing non-price policies, can substantially reduce the economic cost of achieving water 92 consumption reductions (Collinge 1994; Krause et al. 2003; Brennan et al. 2007). 
In order to illustrate the basic economics, we can examine one typical CAC approach to

94 water conservation - a citywide required demand reduction achieved by uniformly restricting

95 outdoor uses. Figure 1 portrays two households with the same indoor demand curves, but

96 different preferences with respect to outdoor demand. The difference in slopes of the three

97 demand curves is associated with differences in elasticity - the percentage change in demand

98 prompted by a one percent price increase. (For all but one specific class of demand function,

99 price elasticity varies along the demand curve, thus while we can speak broadly about

100 comparisons across demand curves, there may be points on a relatively steep demand curve at

101 which price elasticity exceeds that on some parts of a flat demand curve.) Here we assume that

102 indoor demand (frame $\mathrm{C}$ in Figure 1), the steepest curve, is inelastic, because indoor uses are less

103 easily reduced in response to price changes, reflecting the basic needs met by indoor water use.

104 For outdoor demand, there is a relatively elastic household (Panel A), and a somewhat less

105 elastic household (Panel B). The more elastic household is more likely to reduce outdoor demand

106 in response to a price increase - perhaps because it has weaker preferences for outdoor

107 consumption (e.g., in the short run, it would rather allow the lawn to turn brown than pay a

108 higher water bill to keep it green).

109 Unregulated, with price set at $\bar{P}$, both households consume $Q_{C}$ units of water indoors, the

110 less elastic household consumes $Q_{B}^{\text {unreg }}$ outdoors, and the more elastic household consumes $Q_{A}^{\text {unreg }}$

111 outdoors. Outdoor reduction mandated under a CAC approach (which leaves indoor use

112 unchanged, and reduces outdoor uses to $Q_{B}^{\text {reg }}$ and $Q_{A}^{\text {reg }}$ ) creates a "shadow price" for outdoor

113 consumption $(\lambda)$ that is higher under the current marginal price $(\bar{P})$ for household $\mathrm{B}$ than for

114 household A, because household B is willing to pay more for an additional unit of water than

115 household $\mathrm{A}$. If instead the water supplier charges price $P^{*}$, that achieves the same aggregate 
116 level of water conservation as the prescriptive approach, consumers would realize all potential

117 gains from substitution within and across households, erasing the shaded deadweight loss (DWL)

118 triangles. Consumption moves to $Q_{C}^{*}$ indoors for both types of households, and to $Q_{A}^{*}$ and $Q_{B}^{*}$

119 outdoors. The savings from the market-based approach are driven by two factors: (1) the ability

120 of households facing higher prices rather than quantity restrictions to decide which uses to

121 reduce according to their own preferences; and (2) allowing heterogeneous responses to the

122 regulation across households, resulting in substitution of scarce water from those households

123 who value it less, to those who value it more.

124 How large are the losses from non-price demand management approaches when 125 examined empirically? We know of only three cases in which the welfare losses from 126 prescriptive water conservation policies have been estimated. Timmins (2003) compared a

127 mandatory low-flow appliance regulation with a modest water price increase, using aggregate 128 consumption data from 13 groundwater-dependent California cities. Under all but the least 129 realistic of assumptions, he found prices to be more cost-effective than technology standards in 130 reducing groundwater aquifer lift-height in the long run.

131 Another study of 11 urban areas in the United States and Canada compared residential 132 outdoor watering restrictions with drought pricing (Mansur and Olmstead 2007). For the same 133 level of aggregate demand reduction as implied by a two-day-per-week outdoor watering 134 restriction, the establishment of a market-clearing drought price in these cities would result in 135 welfare gains of approximately $\$ 81$ per household per summer drought. This represents about 136 one-quarter of the average household's total annual water bill in the study.

137 Using a different approach, Brennan et al. (2007) constructed a household production 138 model to estimate the welfare cost of urban outdoor water restrictions in Perth, Australia, and 
139 arrived at similar conclusions. The household welfare costs of a two-day-per-week sprinkling

140 restriction are just under $\$ 100$ per household per season, and the costs of a complete outdoor

141 watering ban range from $\$ 347-\$ 870$ per household per season.

142 Based on both economic theory and empirical estimates, the inescapable conclusion is

143 that using price increases to reduce demand, allowing households, industrial facilities, and other

144 consumers to adjust their end-uses of water is more cost-effective than implementing non-price

145 demand management programs.

147 3. Predictability in Achieving Water Conservation Goals

$148 \quad 3.1 \quad$ Effects of Price on Water Demand

149 If policymakers are to use prices to manage demand, the key variable of interest is the

150 price elasticity of water demand. Because an increase in the price of water leads consumers to

151 demand less of it, all else equal, price elasticity is a negative number. (Elasticity figures may

152 also be reported in absolute value, and the negative sign is then implicit. We use the more

153 conventional negative sign in this paper.) An important benchmark in elasticity is -1.0 ; this

154 figure divides demand curves into the categories of elastic and inelastic.

155 There is a critical distinction between "inelastic demand" and demand which is

156 "unresponsive to price". If demand is truly unresponsive to price, price elasticity is equal to

157 zero, and the demand curve is a vertical line - the same quantity of water will be demanded at

158 any price. This may be true in theory for a subsistence quantity of drinking water, but it has not

159 been observed for water demand more broadly in fifty years of empirical economic analysis.

160 That said, water demand in the residential sector is sensitive to price, but demand is

161 inelastic at current prices. In a meta-analysis of 124 estimates generated between 1963 and 
162 1993, accounting for the precision of estimates, Espey et al. (1997) obtained an average price 163 elasticity of -0.51 , a short-run median estimate of -0.38 , and a long-run median estimate of -

164 0.64. Likewise, Dalhuisen et al. (2003) obtained a mean price elasticity of -0.41 in a meta165 analysis of almost 300 price elasticity studies, 1963-1998. And a recent, comprehensive study of 166 water demand in eleven urban areas in the United States and Canada found that the price 167 elasticity of water demand was approximately -0.33 (Olmstead et al. 2007). The price elasticity 168 of residential demand varies substantially across place and time, but on average, in the United 169 States, a $10 \%$ increase in the marginal price of water in the urban residential sector can be 170 expected to diminish demand by about three to four percent in the short run. This is similar to 171 empirical estimates of the price elasticity of residential energy demand (Bohi and Zimmerman 172 1984, Bernstein and Griffin 2005).

173 There are some important caveats worth mentioning. First, elasticities vary along a 174 demand curve, and any estimate represents an elasticity at a specific price, in particular, actual 175 (current) prices. Were prices to approach the efficient levels discussed earlier, water demand 176 would likely be much more sensitive to price increases.

177 Second, consumers are relatively more sensitive to water prices in the long run than they 178 are in the short run, because over longer time periods, capital investments are not fixed. For 179 example, households might change appliance stocks, retrofit water-using fixtures, or alter 180 landscaping from lawns to drought-tolerant plants; firms can be expected to change water181 consuming technologies, increase recycling, or relocate to areas in which water is more plentiful. 182 In the long run, a 10\% price increase can be expected to decrease demand by about six percent.

183 Third, price elasticities vary with many other factors. In the residential sector, high184 income households tend to be much less sensitive to water price increases than low-income 
185 households. Also, price elasticity may increase by 30 percent or more when price information is

186 posted on water bills (Gaudin 2006). And price elasticity may be higher under increasing-block

187 prices (in which the marginal volumetric water price increases with consumption) than under

188 uniform volumetric prices (Olmstead et al. 2007). Price elasticities must be interpreted in the

189 context in which they have been derived.

\section{$190 \quad 3.2 \quad$ Effects of Non-price Conservation Programs on Water Demand}

191 Historically, water suppliers have relied on non-price conservation programs to induce

192 demand reductions during shortages. We consider the effects of such non-price programs in

193 three categories: (1) required or voluntary adoption of water-conserving technologies; (2)

194 mandatory water use restrictions; and (3) mixed non-price conservation programs.

195 3.2.1 Required or Voluntary Adoption of Water-Conserving Technologies

196 Many urban water utilities have experimented with required or voluntary adoption of

197 low-flow technologies. (Since the 1992 Energy Policy Act, U.S. law has required the installation

198 of low-flow toilets and showerheads in all new residential construction, but some cities have also

199 mandated or encouraged retrofitting.) When water savings from these programs have been

200 estimated, they have often been smaller than expected, due to behavioral changes that partially

201 offset the benefit of greater technical efficiency. For example, households with low-flow

202 showerheads may take longer showers than they would without these fixtures (Mayer et al.

203 1998). The necessity of the "double flush" was a notorious difficulty with early models of low-

204 flow toilets. In a recent demonstration of similar compensating behavior, randomly-selected

205 households had their top-loading clotheswashers replaced with more water efficient, front-

206 loading washers. In this field trial, the average front-loading household increased clothes- 
207 washing by 5.6 percent, perhaps due to the cost savings associated with the appliances' increased 208 efficiency (Davis 2006).

209 Several engineering studies have observed a small number of households in a single 210 region to estimate the water savings associated with low-flow fixtures. But most of these studies 211 used intrusive data collection mechanisms, attaching equipment to faucets and other fixtures in 212 homes (Brown and Caldwell 1984). Study participants were aware they were being monitored as 213 they used water, which may have led to confounding behavioral changes.

214 One comprehensive study that was not characterized by this monitoring problem 215 indicates that households fully constructed or retrofitted with low-flow toilets used about 20 216 percent less water than households with no low-flow toilets. The equivalent savings reported for 217 low-flow showerheads was 9 percent (Mayer et al. 1998). Careful studies of low-flow 218 showerhead retrofit programs in the East Bay Municipal Utility District, California, and Tampa, 219 Florida estimate water savings of 1.7 and 3.6 gallons per capita per day (gpcpd), respectively 220 (Aher et al. 1991; Anderson et al. 1993). In contrast, showerhead replacement had no 221 statistically significant effect in Boulder, Colorado (Aquacraft 1996). Savings reported for low222 flow toilet installation and rebate programs range from 6.1 gpcpd in Tampa, Florida to 10.6 223 gpcpd in Seattle, Washington (U.S. General Accounting Office 2000). Renwick and Green 224 (2000) estimate no significant effect of ultra low-flush toilet rebates in Santa Barbara, California. 225 It is not surprising that studies of the water savings induced by such policies vary widely, 226 from zero to significant water savings - the scope and nature of policies vary widely, as well. 227 More important than the raw water savings induced by these programs, however, is the cost per 228 gallon saved, in comparison with alternative policies. The costs of toilet retrofit policies 229 implemented in U.S. cities range from less than $\$ 100,000$ to replace 1,226 toilets in Phoenix, 
231 Office 2000). These can be expensive programs, but in most cases no analysis is done to

232 estimate the magnitude of price increases that would have induced demand reductions equivalent

233 to those observed with technology standards. Only with such information can price and non-

234 price demand management programs be compared as policy options on the basis of cost.

\section{3.2.2 Mandatory Water-Use Restrictions}

Non-price management tools also include utility implementation of mandatory water use

237 restrictions, much like the traditional command-and-control approach to pollution regulation.

238 These include restrictions on the total quantity of water that can be used, as well as restrictions

239 on particular water uses, usually outdoors, such as lawn-watering and car-washing. Empirical

240 evidence regarding the effects of these programs is mixed. Summer 1996 water consumption

241 restrictions in Corpus Christi, Texas, including prohibitions on landscape irrigation and car-

242 washing, did not prompt statistically significant water savings in the residential sector (Schultz et

243 al. 1997). However, a longer-term program in Pasadena, California resulted in aggregate water

244 savings (Kiefer et al. 1993), as did a program of mandatory water use restrictions in Santa

245 Barbara, California (Renwick and Green 2000).

246 3.2.3 Mixed Non-Price Conservation Programs

247 Water utilities often implement a variety of non-price conservation programs

248 simultaneously, making it difficult to determine the effects of individual policies. One analysis

249 of the effect of conservation programs on aggregate water district consumption in California

250 found small but significant reductions in total water use attributable to landscape education

251 programs and watering restrictions, but no effect due to non-landscape conservation education

252 programs, low-flow fixture distribution, or the presentation of drought and conservation 
253 information on customer bills (Corral 1997). Another study of southern California cities found

254 that the number of conservation programs in place in a city had a small negative impact on total

255 residential water demand (Michelsen et al. 1998). An aggregate demand study in California

256 found that public information campaigns, retrofit subsidies, water rationing, and water use

257 restrictions had negative and statistically significant impacts on average monthly residential

258 water use, and the more stringent policies had stronger effects than voluntary policies and

259 education programs (Renwick and Green 2000).

\section{3.2.4. Summing up the predictability comparison}

261 Predictability of the effects of a water conservation policy may be of considerable

262 importance to water suppliers, although in most cases the objective of water conservation

263 policies is water savings, without any specific target in mind. In this case, an estimate of the

264 reduction expected from policy implementation is necessary, but precision is less important.

265 If certainty is required, economic theory would suggest that the quantity restrictions

266 typical of traditional, prescriptive approaches to water demand management would be preferred

267 to price increases, particularly if water suppliers could be sure of near-total compliance, or at

268 least be able to adjust their water savings target upward to account for a reliable estimate of the

269 noncompliance rate (Weitzman 1973). But suppliers generally cannot rely on substantial

270 compliance with quantity-based restrictions. In a comprehensive study of drought management

271 policies among 85 urban water utilities during a prolonged drought in Southern California,

272 analysts reported that 40 agencies adopted mandatory quantity restrictions, but also found that

273 more than half of the customers violated the restrictions (Dixon et al. 1996). Such non-binding

274 quantity constraints are common, but how are utilities to predict the water savings achievable

275 through quantity restrictions when less than half of consumers typically comply? In the same 
276 study, about three-quarters of participating urban water agencies implemented type-of-use

277 restrictions (most of them mandatory). Few penalties were reported, and enforcement was weak, 278 again raising questions regarding compliance. With such low rates of compliance with

279 traditional quantity-based regulations, neither price nor non-price demand management programs

280 have an advantage in terms of predicting water demand reductions.

\section{Equity and Distributional Considerations}

The main distributional concern with a market-based approach to urban water

284 management arises from the central feature of a market - allocation of a scarce good by

285 willingness to pay (WTP). Under some conditions, WTP may be considered an unjust allocation

286 criterion. Think, for example, about the negative reaction to selling food and water to the highest

287 bidder in the aftermath of a natural disaster. This sense that there are some goods and services

288 that should not be distributed by markets in particular contexts is behind the practice of rationing

289 during wartime. A portion of water in residential consumption is used for basic needs, such as

290 drinking and bathing. "Lifeline" rates and other accommodations ensuring that water bills are

291 not unduly burdensome for low-income households are common. Thus, policymakers

292 considering market-based approaches to water management must be concerned about equity in

293 policy design.

294 What does the empirical evidence tell us about the equity implications of water pricing as

295 a conservation tool? Agthe and Billings (1987) found that low-income households exhibited a

296 larger demand response to price increases in Tucson, Arizona, but the study did not compare the

297 distributional effects of price and non-price approaches. Renwick and Archibald (1998) found

298 that low-income households in two Southern California communities were more price-responsive 
299 than high-income households, reflecting water expenditures' larger share of the household 300 budget. Thus, if water demand management occurs solely through price increases, low-income 301 households will contribute a greater fraction of the cities' aggregate water savings than high302 income households. This is not surprising to economists - price elasticity tends to decline with 303 the fraction of household income spent on a particular good.

304 Importantly, the distributional implications of non-price policies vary by type. For 305 example, requiring particular landscape irrigation technologies results in demand reduction 306 mainly among higher-income households (Renwick and Archibald 1998).

307 Mansur and Olmstead (2007) examined the distributional impacts of various demand 308 management policies, and found that raising prices to reduce consumption would cause a greater 309 consumption reduction for low-income than for high-income households. (If we return to Figure 3101 and assume that households of type A are low-income and type B are high-income, we can see 311 why this happens.)

312 The fact that price-based approaches are regressive in water consumption does not mean 313 they are necessarily regressive in cost. Likewise, the fact that non-price programs are progressive 314 in water consumption does not mean they are progressive in cost. The impact of non-price 315 programs on distributional equity depends largely on how a non-price program is financed. And 316 progressive price-based approaches to water demand management can be designed by returning 317 utility profits (from higher prices) in the form of rebates. In the case of residential water users, 318 this could occur through the utility billing process.

319 Drought pricing, like LRMC pricing, would cause utilities to earn substantial short-run 320 profits (Mansur and Olmstead 2007). These profits would have to be returned to consumers in 321 some form, as regulated utilities usually are required to earn zero or very low profits. Profits 
322 could be re-allocated based upon income, in order to achieve equity goals. Any rebate scheme

323 that is not tied to current consumption can retain the strong economic-incentive benefits of

324 drought pricing, without imposing excessive burdens on low-income households, relative to

325 traditional approaches.

\section{5. Monitoring and Enforcement}

Price-based approaches to water demand management hold a substantial advantage over

329 non-price approaches in regard to administrative costs for monitoring and enforcement. Non-

330 price demand management policies require that water suppliers monitor and enforce restrictions

331 on particular fixtures, appliances, and other technologies that customers use indoors and out, the

332 particular days of the week or times of day that customers use water for specific purposes, and in

333 some cases, the quantity used for each purpose.

334 The great difficulty in monitoring and enforcing these types of command-and-control

335 approaches is one reason for the prevalence of outdoor watering restrictions - outdoor uses are

336 usually visible, and it is relatively easy to cruise residential streets searching for violators.

337 Overall, monitoring and enforcement problems explain the low rates of compliance with many

338 non-price demand management programs. Where low-flow fixtures are encouraged or required,

339 they are often replaced with their higher-flow alternatives if consumers are dissatisfied with 340 performance.

341 In contrast, non-compliance in the case of pricing requires that households consume

342 water "off meter," since water consumption is metered and billed volumetrically in most U.S.

343 cities. Of course, higher prices generate incentives not only for conservation, but also for

344 avoidance. However, at prevailing prices and even with substantial price increases, the 
345 monitoring and enforcement requirements of price changes are likely to be far less significant

346 than those of a comparable non-price approach.

\section{$348 \quad$ 6. Political Considerations}

349 Water demand management through non-price techniques is the overwhelmingly

350 dominant paradigm in cities around the world. Raising prices, particularly for what people

351 perceive to be a "public service" (though water is supplied by both public and private entities),

352 can be politically difficult. After a two-year drought in the late 1970s, the city of Tucson,

353 Arizona was the first U.S. city to adopt marginal-cost water prices, which involved a substantial

354 price increase. One year later, the entire Tucson city council was voted out of office due to the

355 water rate increase (Hall 2000). Just as few elected officials relish the prospect of raising taxes,

356 few want to increase water rates.

357 Ironically, non-price programs are more expensive to society than water price increases, 358 once the real costs of programs and associated welfare losses are considered. A parallel can be

359 drawn in this case to market-based approaches to environmental pollution control, including

360 taxes and tradable permit systems. Cost-effectiveness has only recently been accepted as an

361 important criterion for the selection of policies to control pollution (Keohane et al. 1998).

362 Despite empirical evidence regarding their higher costs, political constituencies that prefer non-

363 price approaches have succeeded in preventing management through prices. Some of this

364 resistance to using prices may be due to misinformation, since most policymakers and water

365 customers are not aware of the cost-effectiveness advantage of the price-based approach. For

366 example, a common misconception in this regard is that price elasticity is "too low to make a 367 difference". 
Non-price demand management techniques can create political liabilities in the form of 369 water utility budget deficits. Non-price conservation programs are costly. In addition, if these 370 policies actually reduce demand, water utility revenues decline. During prolonged droughts,

371 these combined effects can result in the necessity for substantial price increases following 372 "successful" non-price conservation programs, simply to prevent water utilities from 373 unsustainable financial losses. This occurred in 1991 in southern California. During a prolonged 374 drought, Los Angeles water consumers responded to the Department of Water and Power's 375 request for voluntary water use reductions. Total use and total revenues fell by more than 20 376 percent. As a result, the Department requested a rate increase to cover its growing losses (Hall 377 2000). In contrast, given urban price elasticities common in the United States, price increases 378 will increase water suppliers' total revenues. The extra per-unit revenues from a price increase 379 outweighs lost revenue from the decreased demand.

380 The costs of inefficient water pricing and the relative cost advantages of price over non381 price water demand management programs are clear. But like other subsidies, low water prices 382 (on a day-to-day basis, as well as during periods of drought) are popular and politically difficult 383 to change. Some communities may be willing to continue to bear excessive costs from 384 inefficient water pricing, in exchange for the political popularity of low prices. In other cases, 385 rate-setting officials may be constrained by law, unable to increase water prices by a percentage 386 that exceeds some statutory maximum. In these cases, the tradeoffs involved should be 387 measured and made explicit to water customers. 


\section{Conclusions}

Using prices to manage water demand is more cost-effective than implementing non-

391 price conservation programs. The gains from using prices as an incentive for conservation come

392 from allowing households to respond to increased water prices in the manner of their choice,

393 rather than by installing a particular technology or reducing particular uses, as prescribed by non-

394 price approaches. Price-based approaches also have important advantages in terms of monitoring 395 and enforcement.

In terms of predictability, neither policy instrument has an inherent advantage over the 397 other. Likewise, neither policy instrument has a natural advantage in terms of equity. Under

398 price-based approaches, low-income households are likely to contribute a greater share of a 399 city's aggregate water consumption reduction than they do under certain types of non-price 400 demand management policies. But progressive price-based approaches to water demand 401 management can be developed by returning some utility profits due to higher prices in the form 402 of consumer rebates. Such rebates will not significantly dampen the effects of price increases on 403 water demand, as long as rebates are not tied to current water consumption.

404 Raising water prices (like the elimination of any subsidy) is politically difficult, but there 405 may be political capital to be earned by elected officials who can demonstrate the cost406 effectiveness advantages of the price-based approach. At a minimum, communities choosing 407 politically popular low water prices over cost-effectiveness should quantify this tradeoff and 408 make it explicit. Where water rate-setting officials are constrained by law from raising water 409 prices, during droughts or in general, a discussion of the real costs of these constraints would be 410 useful. 
411 We are reminded of the debate, beginning in the late 1980s, over market-based 412 approaches to pollution control. While some opponents of environmental taxes and tradable 413 permit systems still resist these approaches, policymakers have succeeded in implementing them 414 in many cases, achieving impressive pollution reductions at great cost savings over more 415 prescriptive approaches. A similar shift in the area of water conservation, where the principles 416 are essentially the same, is long overdue.

417

418

\section{Acknowledgments}

420 The authors are grateful for financial support from the Pioneer Institute for Public Policy 421 Research. 
Figure 1. Welfare Losses from Outdoor Consumption Restrictions with Heterogeneous Outdoor Demand
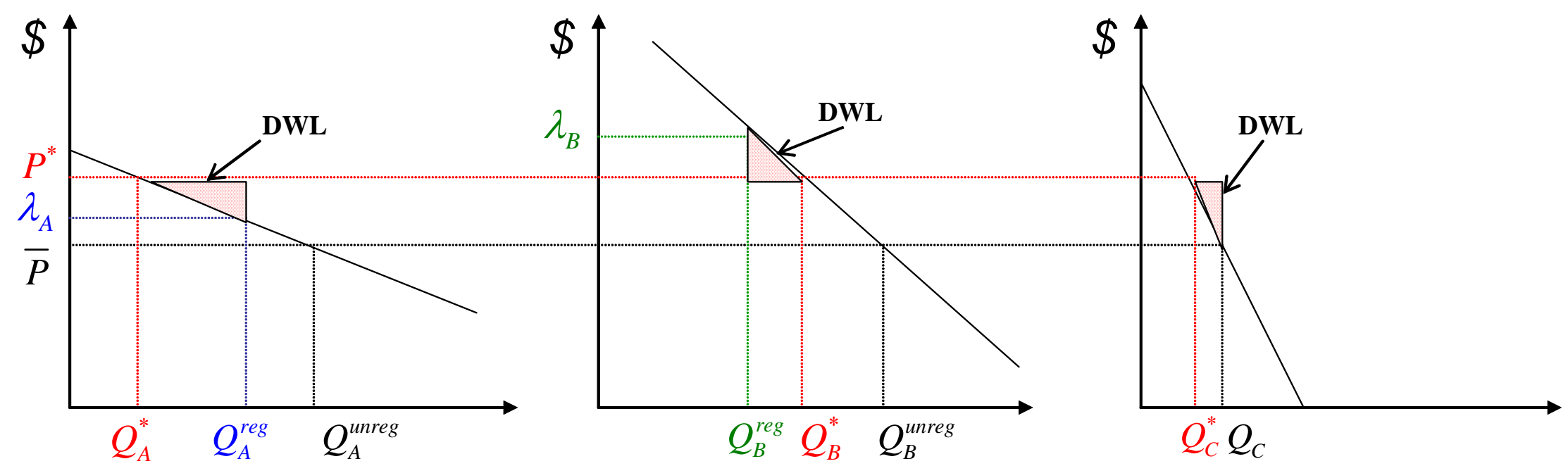

A

Relatively Elastic Outdoor Demand
B

Somewhat Less Elastic Outdoor Demand
C

Inelastic

Indoor Demand

(Where $P^{*}$ is the market-clearing price for $Q_{A}^{\text {reg }}+Q_{B}^{\text {reg }}+Q_{C}=Q_{A}^{*}+Q_{B}^{*}+Q_{C}^{*}$ ). 


\section{References}

Agthe, D. E., and R. B. Billings (1987), Equity, price elasticity, and household income under increasing block rates for water, Am. J. Econ. and Sociol., 46(3), 273-286.

Aher, A., A. Chouthai, L. Chandrasekar, W. Corpening, L. Russ, and B. Vijapur (1991), East Bay Municipal Utility District Water Conservation Study, Stevens Institute of Technology, Oakland, CA.

Anderson, D. L., D. Mulville-Friel, and W. L. Nero (1993), The impact of water conserving fixtures on residential water use characteristics in Tampa, Florida, in Proceedings of Conserv93, pp. 611-628, American Waterworks Association, Las Vegas, NV.

Aquacraft Water Engineering and Management (1996), Project Report: Measuring Actual Retrofit Savings and Conservation Effectiveness Using Flow Trace Analysis, prepared for the City of Boulder, Colorado, Utilities Division, Office of Water Conservation, Boulder, CO.

Baumol, W. J., and W. E. Oates (1988), The Theory of Environmental Policy, $2^{\text {nd }}$ ed., 299 pp., Cambridge Univ. Press, New York.

Bernstein, M. A., and J. Griffin (2005), Regional differences in the price elasticity of demand for energy, RAND Technical Report, Santa Monica, CA.

Bohi, D. R., and M. B. Zimmerman (1984), An update on econometric studies of energy demand behavior, Annu. Rev. Energy 9, November, 105-154.

Brennan, D., S. Tapsuwan, and G. Ingram (2007), The welfare costs of urban outdoor water restrictions, Australian J. Agric. and Resour. Econ., 51, 243-261.

Brewer, J., R. Glennon, A. Ker, and G. Libecap (2007), Transferring water in the American West: 1987-2005, U. Mich. J. Law Reform, 40(4), 1021-1053.

Brown, T. C. (2006), Trends in water market activity and price in the western United States, Water Resour. Res. 42, W09402, doi:10.1029/2005WR004180.

Brown and Caldwell Consulting Engineers (1984), Residential Water Conservation Projects, U.S. Department of Housing and Urban Development, Washington, D.C.

Collinge, R. A. (1994), Transferable rate entitlements: The overlooked opportunity in municipal water pricing, Pub. Fin. Quarterly 22(1), 46-64.

Corral, L. R. (1997), Price and non-price influence in urban water conservation, Ph.D. dissertation, 90 pp., Univ. of Calif., Berkeley, Spring.

Crocker, T. D. (1966), The structuring of atmospheric pollution control systems, in The Economics of Air Pollution, edited by H. Wolozin, Norton, New York. 
Dales, J. (1968), Pollution, Property and Prices, 111 pp., University Press, Toronto.

Dalhuisen, J. M., R. J. G. M. Florax, H. L. F. de Groot, and P. Nijkamp (2003), Price and income elasticities of residential water demand: A meta-analysis, Land Econ., 79(2), 292-308.

Davis, L. W. (2006), Durable goods and residential demand for energy and water: Evidence from a field trial, RAND J. Econ., forthcoming.

Dixon, L. S., N. Y. Moore, and E. M. Pint (1996), Drought Management Policies and Economic Effects in Urban Areas of California, 1987-1992, 131 pp., RAND, Santa Monica, CA.

Espey, M., J. Espey, and W. D. Shaw (1997), Price elasticity of residential demand for water: A meta-analysis, Water Resour. Res., 33(6), 1369-1374.

Gaudin, S. (2006), Effect of price information on residential water demand, Appl. Econ., 38, 383393.

Hall, D. C. (2000), Public choice and water rate design, in The Political Economy of Water Pricing Reforms, edited by A. Dinar, pp. 189-212, Oxford Univ. Press, New York.

Hanemann, W. M. (1997), Price and rate structures, in Urban Water Demand Management and Planning, edited by D. D. Baumann et al., pp. 137-179, McGraw-Hill, New York.

Howe, C. W. (1997), Increasing efficiency in water markets: Examples from the Western United States, in Water Marketing -- The Next Generation, edited by T. L. Anderson and P. J. Hill, pp. 79-100, Rowman and Littlefield, Lanham, MD.

Hutson, S. S., N. L. Barber, J. F. Kenny, K. S. Linsey, D. S. Lumia, and M. A. Maupin (2004), Estimated Use of Water in the United States in 2000, USGS Circular 1268, U.S. Geological Survey, Washington, D.C., March.

Keohane, N. O. (2007), Cost savings from allowance trading in the 1990 Clean Air Act, in Moving to Markets in Environmental Regulation: Lessons from Twenty Years of Experience, edited by C. E. Kolstad and J. Freeman, Oxford Univ. Press, New York.

Keohane, N. O., R. L. Revesz, and R. N. Stavins (1998), The choice of regulatory instruments in environmental policy, Harvard Environ. Law Rev., 22(2), 313-367.

Kiefer, J. C., and B. Dziegielewski (1991), Analysis of Residential Landscape Irrigation in Southern California, Report prepared for the Metropolitan Water District of Southern Calif. by Planning and Management Consultants, Ltd., Carbondale, IL.

Kolstad, C. E., and J. Freeman (Eds.) (2007), Moving to Markets in Environmental Regulation: Lessons from Twenty Years of Experience, Oxford Univ. Press, New York. 
Krause, K., J. M. Chermak, and D. S. Brookshire (2003), The demand for water: Consumer response to scarcity, J. Regul. Econ., 23(2), 167-191.

Mansur, E. T., and S. M. Olmstead (2007), The value of scarce water: Measuring the inefficiency of municipal regulations, NBER Working Paper No. 13513, October.

Mayer, P. W., W. B. DeOreo, E. M. Opitz, J. C. Kiefer, W. Y. Davis, B. Dziegielewski, and J. O. Nelson (1998), Residential End Uses of Water, American Waterworks Association Research Foundation, Denver, CO.

Michelsen, A. M., J. T. McGuckin, and D. M. Stumpf (1998), Effectiveness of Residential Water Conservation Price and Nonprice Programs, 128 pp., American Water Works Association Research Foundation, Denver, CO.

Montgomery, D. (1972), Markets in licenses and efficient pollution control programs, J. Econ. Theory, 5, 395-418.

Newell, R. N., and R. N. Stavins (2003), Cost heterogeneity and the potential savings from market-based policies, J. Regul. Econ., 23(1), 43-59.

Olmstead, S. M., W. M. Hanemann, and R. N. Stavins (2007), Water demand under alternative price structures, J. Environ. Econ. Manage., 54(2), 181-198.

Panayotou, T. (1998), Instruments of Change: Motivating and Financing Sustainable Development, 228 pp., Earthscan, London.

Parry, I. W. H., and A. Bento (2002), Estimating the welfare effect of congestion taxes: The critical importance of other distortions within the transport system, J. Urban Econ., 51, 339-365.

Pels, E., and E. T. Verhof (2004), The economics of airport congestion pricing, J. Urban Econ., 55, 257-277.

Pigou, A.C. (1920), The Economics of Welfare, Macmillan \& Co., London.

Renwick, M. E., and S. O. Archibald (1998), Demand side management policies for residential water use: Who bears the conservation burden?, Land Econ., 74(3), 343-359.

Renwick, M. E., and R. D. Green (2000), Do residential water demand side management policies measure up? An analysis of eight California water agencies, J. Environ. Econ. Manage., 40(1), 37-55.

Renzetti, S. (1992), Evaluating the welfare effects of reforming municipal water prices, $J$. Environ. Econ. Manage., 22(2), 147-163. 
Russell, C., and B. Shin (1996), Public utility pricing: Theory and practical limitations, in Marginal Cost Rate Design and Wholesale Water Markets, Advances in the Economics of Environmental Resources, Volume 1, edited by D. Hall, pp. 123-139, JAI Press, Greenwich, CT.

Schultz, M. T., S. M. Cavanagh (Olmstead), B. Gu, and D. J. Eaton (1997), The Consequences of Water Consumption Restrictions during the Corpus Christi Drought of 1996, draft report, LBJ School of Public Affairs, University of Texas, Austin.

Sibly, H. (2006), Efficient urban water pricing, Australian Econ. Rev., 39, 227-237.

Stavins, R. N. (2003), Market-based environmental policy instruments, in Handbook of Environmental Economics, Volume 1: Environmental Degradation and Institutional Responses, edited by K.-G. Mäler and J. R. Vincent, pp. 355-435, Elsevier Science, Amsterdam.

Sterner, T. (2003), Policy Instruments for Environmental and Natural Resource Management, 504 pp., Resources for the Future, Washington, DC.

Teitenberg, T. (2006), Emissions Trading: Principles and Practice, $2^{\text {nd }}$ ed., 231 pp., Resour. for the Future, Washington, D.C.

Timmins, C. (2003), Demand-side technology standards under inefficient pricing regimes: Are they effective water conservation tools in the long run? Environ. Resour. Econ., 26, 107-124.

U.S. General Accounting Office (2000), Water infrastructure: Water-efficient plumbing fixtures reduce water consumption and wastewater flows, Report to Congressional Requesters, GAO/RCED-00-232, Washington, D.C., August.

Weitzman, M. L. (1973), Prices vs. quantities, Rev. Econ. Stud., 41(4), 477-491. 